\title{
Surface storm flow prediction on hillslopes based on topography and hydrologic connectivity
}

\author{
Dennis W. Hallema ${ }^{1,2,3^{*}}$, Roger Moussa ${ }^{1}$, Ge Sun${ }^{2}$ and Steven G. McNulty ${ }^{2}$
}

\begin{abstract}
Background: Hillslopes provide critical watershed ecosystem services such as soil erosion control and storm flow regulation through collecting, storing, and releasing rain water. During intense rainstorms, rainfall intensity and infiltration capacity on the hillslope control Hortonian runoff while the topographic attributes of the hillslope (e.g., slope, aspect, curvature) and the channel network define the structural hydraulic connectivity that determines how rapidly excess water is transferred. This paper discusses literature on the link between topographic attributes and hydrologic connectivity and demonstrates how this link can be used to define a parsimonious model for predicting surface runoff during high intensity rainfall.

Main text: First, we provide a topographic characterization of the hillslope necessary to determine the structural hydrologic connectivity of surface flow based on existing literature. Subsequently, we demonstrate a hydrologic surface response model that routes the geomorphologic unit hydrograph (GIUH) through a spatial domain of representative elementary hillslopes reflecting the structural hydrologic connectivity. Topographic attributes impact flow and travel time distributions by affecting gravitational acceleration of overland flow and channel, solar irradiance, flow deceleration by vegetation, and flow divergence/convergence.

Conclusions: We show with an example where we apply the GIUH-based model to hypothetical hillslopes that the spatial organization of the channel network is critical in the flow and travel time distribution, and that topographic attributes are key in obtaining simple yet accurate representations of hydrologic connectivity. Parsimonious GIUH models of surface runoff that use this hydrologic connectivity have the advantage of low data requirements, being scalable and applicable regardless of the spatial complexity of the hillslope, and have the potential to fundamentally improve flood forecasting tools used in the assessment of ecosystem services.
\end{abstract}

Keywords: Hydrological processes, Hydrologic connectivity, Storm flow, Ecosystem services, GIUH

\section{Review}

Introduction

Hillslopes provide critical water-related ecosystem services to the society by maintaining baseflow and groundwater flow used for drinking water, agricultural irrigation, recreation and industry, and by acting as a temporary storage buffer to reduce flood peaks and

\footnotetext{
*Correspondence: dwhallem@ncsu.edu

'INRA, UMR LISAH Laboratoire d'étude des Interactions Sol-AgrosystèmeHydrosystème (INRA, IRD, Montpellier SupAgro), 2 place Pierre Viala, 34060 Montpellier CEDEX 2, France

${ }^{2}$ U.S. Department of Agriculture Forest Service, Eastern Forest Environmental Threat Assessment Center, Southern Research Station, Raleigh, NC 27606, USA

Full list of author information is available at the end of the article
}

potential damage that may result from flooding (Guswa et al., 2014). The need for exploring practical approaches to river flood risk assessment has increased given the effects of climate changes on flood magnitudes and frequencies in many parts of the world (Arnell and Gosling, 2016). Understanding the hydrologic connectivity between the hillslope and downstream water bodies is essential within this context (McGlynn and McDonnell, 2003; Nelson et al., 2009). Hydrologic connectivity is particularly important for watersheds where storm flow is dominated by rapid surface runoff, such as in mountainous regions with shallow soils, regions with a Mediterranean or semi-arid climate, and in all urban environments (Hallema and Moussa, 2014). The hillslope's 
ability to retain and release water largely controls the hydrologic response over the course of a given rainfall event, and affects the propagation of generated runoff from the hillslope to the nearest channel in response to precipitation (Robinson and Sivapalan, 1996). Flow and travel time distributions along the hillslope can vary considerably due to differences between surface runoff velocities and channel (stream) flow velocities, and will impact how quickly water is delivered to the base of the slope (Bracken and Croke, 2007). In the example of a cultivated hillslope in Southern France, channel flow velocities during rainstorms were only 6.3 times faster than surface runoff velocities $\left(0.5\right.$ vs. $0.08 \mathrm{~m} \mathrm{~s}^{-1}$; Hallema et al., 2013) and significantly impacted peak flows downstream. On the other hand, surface runoff velocities in larger baseflow-dominated watersheds can be less than one-hundredth of typical channel flow velocities (Emmett, 1978), and in these cases, the hillslope acts as buffer attenuating peak flows.

Variations in flow distribution and runoff travel times are to a large extent controlled by the topography and infiltration capacity of the soil. Topography affects the distribution patterns, and flow velocities of soil water and of groundwater (Jencso et al., 2009; McGuire and McDonnell, 2010) tend to follow the surface gradient and elevation (Burt and Butcher, 1986; Seibert et al., 1997; Rodhe and Seibert, 1999), and have an important effect on gravity-driven surface runoff along the hillslopes and in the channel network. Topographic attributes defining the gradient, overall shape, and dimensions of the hillslope can therefore be used to estimate runoff velocities (Bogaart and Troch, 2006; Thommeret et al., 2010). Flow distribution and travel times are also impacted by the timing of the onset of infiltrationexcess (Hortonian) runoff, which depend on the soil moisture content, and the presence of a surface crust (Chahinian et al., 2005; Chahinian et al., 2006). Flow travel times can be very rapid on hillslopes with rainsplash-induced soil surface sealing (Hallema et al, 2013). Flow and travel distribution can be used to characterize the hydrologic response of the hillslope by defining them in terms of hydrologic connectivity (Cammeraat, 2002). In the simplest case, flow and travel distribution is determined by the connectivity along the hillslope, between the hillslope and the watershed, and by a dynamic component represented by the runoff generating mechanism (Hallema and Moussa, 2014). Elements of structural connectivity interact with the watershed hydrological processes that are strongly dependent on the topographic controls imposed by the landscape (Turnbull et al., 2008; Wainwright et al., 2011). Given the connectivity between the hillslope and the watershed, changes in land cover upstream affect river levels in the downstream basin, and can increase flood risk in environments under increasing pressure of agriculture (Zhang and Schilling, 2006) and urban development (Nirupama and Simonovic, 2007).

The need for flood control and hillslope storage of water varies locally depending on climate, geomorphology, land use, proximity to population centers, and hydrologic connectivity between the hillslope, riparian zone, and channel network (Shafroth et al., 2010; Thorp et al., 2010), where human-dominated ecosystems in agricultural and peri-urban environments generally produce more runoff than predominantly natural forest ecosystems (Dunjó et al., 2004). Highly parameterized process-based hydrological models are currently the standard in flood forecasting. However, the complexity and data requirements of process-based distributed models often complicate calibration and validation on real-world watersheds. A more parsimonious approach would use the simplest possible parameterization (i.e., one that matches the intended purpose of the model).

In this paper, we examine the link between topographic attributes of the hillslope and hydrological processes using a literature review, and subsequently, we demonstrate with a simple example how the surface hydrologic connectivity defined by these attributes can be accounted for in a more parsimonious approach to predicting storm runoff, based on the geomorphologic instantaneous unit hydrograph (GIUH).

\section{Topographic characterization of the hillslope}

The interaction between topographic controls and hydrological processes is essential in defining hydrologic connectivity (Bracken and Croke, 2007; Turnbull et al., 2008), and to quantify the interaction, it is necessary to characterize these controls and processes. Topographic attributes can be computed from digital elevation models (DEMs) or digital terrain models (DTMs), and are critical in determining patterns in hydrological processes and identifying drainage networks in watersheds because they define the concentrated flow paths along hillslopes and upstream contributing area (Green et al., 2007).

\section{Topographic attributes}

Topographic attributes such as altitude, slope, aspect, hillslope length, profile curvature, and plan curvature have a large impact on overland flow and transportation processes (Troch et al., 2003; Bogaart and Troch, 2006). An overview of these attributes is given in Table 1. Slope is the rate of change in elevation of the land surface and plays a major role in overland flow generation and transportation processes because it affects the soil depth and controls the gravitational acceleration, where the former influences the amount of material available for erosion and the latter the erosive force of runoff. Aspect, which 
Table 1 Primary and secondary topographic attributes of hillslopes (Bogaart and Troch, 2006; Huggett, 2007)

\begin{tabular}{|c|c|c|}
\hline $\begin{array}{l}\text { Topographical } \\
\text { attributes }\end{array}$ & Description & Correlations \\
\hline Altitude & Height above reference point & $\begin{array}{l}\text { Indicator for climate variables (temperature, precipitation), vegetation, } \\
\text { and soil patterns }\end{array}$ \\
\hline Slope & $\begin{array}{l}\text { Change in elevation ( } 1^{\text {st }} \text { derivative of elevation), } \\
\text { steepness of terrain }\end{array}$ & $\begin{array}{l}\text { Indicator of soil depth, wildland fire spread, overland flow velocity, and } \\
\text { subsurface flow velocity }\end{array}$ \\
\hline Aspect & Compass direction (azimuth) of the steepest slope & $\begin{array}{l}\text { Solar insolation and irradiance, vegetation patterns, evapotranspiration, } \\
\text { ecosystem differentiation }\end{array}$ \\
\hline Hillslope length & Length between foot and peak & Amount of sediment supply for erosion \\
\hline $\begin{array}{l}\text { Profile (slope) } \\
\text { curvature }\end{array}$ & Rate of change in slope ( $2^{\text {nd }}$ derivative of elevation) & $\begin{array}{l}\text { Overland flow acceleration, moisture patterns, erosion and deposition } \\
\text { rates }\end{array}$ \\
\hline $\begin{array}{l}\text { Plan (contour) } \\
\text { curvature }\end{array}$ & Rate of change of aspect ( $1^{\text {st }}$ derivative of aspect) & Converging and diverging flow path, gully erosion, alluvial fans \\
\hline Wetness index & $\begin{array}{l}\text { where } A_{u} \text { is the local upstream contributing area and } \\
\beta \text { is the local slope }\end{array}$ & Moisture and vegetation patterns \\
\hline
\end{tabular}

is the azimuth of the steepest slope is equally important, because it influences solar irradiance and thus the type and density of the vegetation, and thereby indirectly affect the amount of overland flow. Primary topographic attributes have a variety of applications including climate (precipitation) simulation with models such as Parameter-elevation Regressions on Independent Slopes Model (PRISM; Spatial Climate Analysis Service, 2004), which uses elevation, slope, and aspect.

Hillslope length is directly related to drainage density (Bogaart and Troch, 2006), which measures the degree of dissection of the hillslope calculated as the total length of the channel network divided by the drainage area (Tucker and Bras, 1998). In the case of a random channel network, drainage density equals approximately twice the hillslope length. A long hillslope generates more weathering products than a short hillslope, and the long total channel length that comes with a long hillslope will favor a rapid evacuation of eroded material. A related secondary attribute is the wetness index, or topographic wetness index (TWI; Beven and Kirkby, 1979) used in TOPMODEL, which is a function of the upstream contributing area for a certain point and the slope at the same position, and allows for modeling flow paths and characterization of vegetation patterns. The TWI parameter in TOPMODEL is essentially a representation of soil moisture connectivity (Beven and Kirkby, 1979; Bracken et al., 2013).

Profile curvature is the curvature along a flow line parallel to the slope, and is therefore also referred to as slope curvature, and plan curvature is the curvature of contour lines. The former represents the rate of change in slope, and indicates zones of accelerating and decelerating flow, while the latter marks the change in slope aspect, and is often linked with the convergence or divergence of flow and consequently the erosive force of flow. Topographic curvature can be used to map a network of gullies or other small channels under the assumption that the deepest continuous line along a valley bottom, or gully in this case, has a significant plan curvature and at the same time a convergent shape (Thommeret et al., 2010).

\section{Hillslope elements}

An often used concept to describe the hillslope morphology (shape) in terms of topography is the catena, which is a chain or sequence of slope units running from the watershed to the valley floor. The catena can be subdivided according to two types of slope units: segments and elements (Young, 1971). A hillslope segment is a portion of the slope profile with a constant slope (slope being a primary topographic attribute). A hillslope element is defined using a secondary topographic attribute: it is a part of the hillslope profile with a more or less constant profile curvature. Several systems have been proposed to name these hillslope elements. One example is the system developed by Dalrymple et al. (1968), which defines a sequence (from watershed divide to valley floor) of interfluve, seepage slope, convex creep slope, fall face, transportational slope, colluvial footslope, and alluvial toeslope. This system, which is similar to a system proposed earlier by Wood (1942) and later adapted by King (1953), combines hydrologic, geomorphic, and geologic characteristics and is very suitable for describing how the hillslope was formed.

However, a purely morphologic classification of hillslope elements based on topographic attributes, such as the one proposed by Ruhe (1960) is preferred for hydrological applications because it provides an indication of flow acceleration on each hillslope element. Using Ruhe's system, hillslope elements can be defined by classifying the profile curvature of the hillslope into five classes (from peak to foot): summit, shoulder, backslope, footslope (or glacis), and toeslope (Table 2) (Ruhe, 1960; 
Table 2 Hillslope elements based on profile curvature (Ruhe, 1960; Huggett, 2007)

\begin{tabular}{ll}
$\begin{array}{l}\text { Hillslope } \\
\text { element }\end{array}$ & Description \\
\hline Summit & $\begin{array}{l}\text { The summit is also referred to as plateau because this relatively flat zone is higher than the rest of the hillslope. Mass wasting } \\
\text { processes are almost absent, leaching and rainsplash dominate. }\end{array}$ \\
Shoulder & $\begin{array}{l}\text { When looking down from the summit, the shoulder below the summit has a slightly convex slope. This is where soil creep can } \\
\text { occur. }\end{array}$ \\
Backslope & $\begin{array}{l}\text { Part of the hillslope with a concave slope between shoulder and footslope called debris slope in the classification of King (1953). } \\
\text { Sediment is deposited on this part of the hillslope because overland flow is slowed down as the slope decreases in downhill } \\
\text { direction. Associated with mass wasting processes such as fall, flows, slides and subsidence. }\end{array}$ \\
Footslope & $\begin{array}{l}\text { Also called glacis, the (often colluvial) footslope is less concave than the backslope above it. This part of the slope is relatively stable } \\
\text { because sediment input is low and the most erosive streams are located downstream of the footslope. }\end{array}$ \\
Toeslope & $\begin{array}{l}\text { The toeslope or valley bottom is rather flat (1-2\% slope) and characterized by alluvial depositions with greater clay and silt content } \\
\text { than upstream parts. Consequently, this is often the part of the hillslope most suitable for agriculture. }\end{array}$ \\
\hline
\end{tabular}

Huggett, 2007). The most active part of the slope in terms of runoff is the slightly concave backslope, or debris slope in King's classification system (King, 1953), where overland flow decelerates as the slope decreases in downhill direction, leading to deposition of sediment. Ruhe's characterization is widely applicable, and many hillslopes contain several of these hillslope elements depending on the local geology.

\section{Relation between topography and scale-dependent proper- ties of channel networks}

The drainage pattern or channel (stream) network is correlated with local topography and traverses the catena and downstream watershed. Hack and Goodlett (1960) used a spatial subdivision of headwater systems into four topographic units: (1) hillslopes; (2) zero-order catchments; (3) ephemeral channels emerging from zero-order catchments; and (4) first- and second channels depending on the linkage between hillslopes and channels, and the stream order classification. This spatial subdivision has historically been applied to the scale of a drainage basin, but also to first-order catchments with an area $<1000 \mathrm{~m}^{2}$ (Uchida et al., 2005). A zero-order catchment defines the minimum drainage area from which the generated runoff has sufficient force to initiate channel development (Schaefer et al., 1979). It has no permanently conducting channels by definition and extends from the water divide to the point where first-order streams begin. The location where the first-order channel begins (the channel head) is the zero-order outlet. The difference between hillslopes and zero-order catchments is their relative position with respect to the first-order channel: the zero-order catchment is connected only to the headward end of the firstorder channel, whereas the hillslope is connected anywhere along a first- or higher-order channel. Fan and Bras (1998) proposed the term headwater for zero-order catchments that drain directly toward a channel head, and sideslope for hillslopes that drain toward a channel segment.
The channel network along a hillslope or within a watershed is in a presumed optimal state in terms of energy expenditure given the local topography and geology, i.e., a network that tends to minimize its total energy dissipation (Rinaldo et al., 1992; Rodríguez-Iturbe and Rinaldo, 1997). Under natural conditions, streams follow the path of least resistance in downstream direction, often resulting in a dendritic or rectangular drainage pattern with a degree of self-similarity across hillslope, watershed, and basin scales (Mandelbrot, 1982). Realizations of channel networks with a self-similar ramification such as those found in nature can be produced using fractals, which are continuous but non-differentiable functions, and comparison shows that optimal channel network computed from DEMs is very accurate and corresponds well with observed stream networks (Rinaldo et al., 1998). This confirms that the effect of topographic attributes on flow paths and by extension flow distribution and travel time distribution is not only significant at the hillslope scale, but also on smaller and larger scales.

\section{Hillslope surface response processes}

Hillslope surface response during high-intensity storms (maximum intensity $>30 \mathrm{~mm} \mathrm{~h}^{-1}$; Martínez-Casanovas et al., 2002; Hallema et al., 2013) is affected by hydrological processes such as precipitation, evapotranspiration, interception, infiltration, and runoff, which are connected through a complex system of interactions. The hillslope is by no means a closed system and many of the processes communicate with systems above (climate, evapotranspiration) and underneath (geology) the hillslope, and horizontally adjacent systems (downstream and upstream).

\section{Infiltration and runoff generation}

Horton (1933) compared the soil surface to a "diverting dam and head-gate" that divides net precipitation (precipitation received at the top of the vegetation canopy less interception losses) into an infiltration component 
limited by the infiltration capacity of the soil and a surface runoff component. The surface runoff component is commonly known as Hortonian overland flow or infiltration excess overland flow. The infiltration rate is supply controlled (or flux controlled) at the beginning of a storm (preponding infiltration; Rubin, 1966), and as soon as the rainfall rate exceeds the infiltration capacity of the soil surface, infiltration becomes rainpond and the resulting infiltration excess flows off along the land surface as overland flow. In this stadium, infiltration is surface controlled. Whilst infiltration excess overland flow is common under dry initial conditions and on hillslopes with surface sealing, the saturation excess overland flow generating mechanism is more common under temperate climate conditions with frequent, low intensity precipitation, and occurs when the soil is saturated and unable to absorb more water (Dunne and Black, 1970). Under such conditions, infiltration is soil controlled or more specifically, profile controlled when the infiltration capacity of the topsoil exceeds that of the underlying soil layers, and the decline rate of the infiltration capacity depends on soil structure, texture, and water content. A special form of infiltration is channel infiltration, which is the infiltration into the channel bed and results in a loss of water in downstream direction. The reverse process, channel seepage, occurs when groundwater surfaces on the face of a stream bank or exfiltrates into the channel.

\section{Overland flow and concentrated flow}

The excess water that runs off along the hillslope is called overland flow or surface runoff, and flows as unsteady, non-uniform flow over the land surface in the direction of the steepest slope, into a stream, drain, depression, and lake. The amount equals gross precipitation less interception, evaporation, and infiltration. Where overland flow and interrill flow are concentrated, erosive forces form narrow and shallow incisions in the soil that concentrate the turbulent flow into rill flow, which eventually ends up in a stream or river (Huggett, 2007). Under most natural circumstances, overland flow does not occur in the form of unconcentrated sheet flow as described by traditional concepts, but rather as unsteady non-uniform concentrated flow in small rivulets (Dunne, 1978; Beven et al., 2000; Wagener et al., 2004) or, in the case of runoff on agricultural land, as interrill flow (Morgan, 1980). If the erosive forces increase even more, gullies are formed that drain the hillslope into a nearby channel or stream. Concentrated open-channel flow is also unsteady and non-uniform in nature, and is observed in rills, gullies, rivers, streams, or open drains (Chow et al., 1988).

\section{Storm flow and hillslope response}

Storm flow during high-intensity rainfall is a special case of hillslope response characterized by an array of flow types that vary throughout the watershed and are susceptible to time-dependent change depending on topography, climate, soils, geology, land cover, vegetation, seasonality, and disturbance factors including wildland fire, agriculture, forest management activities, and water management. The hillslope response during storm flow depends on direct runoff composed of surface runoff (infiltration excess or saturation excess runoff; Horton, 1938; Dunne and Black, 1970) and subsurface storm flow. Although both mechanisms provide the fast-flow component of runoff (Hewlett and Hibbert, 1967; Agnese et al., 2001), the former has a faster response time than the latter because the residence time of water at the surface is shorter than the residence time of water in the soil. Fast hillslope response occurs on both convex and concave hillslopes, whereas slower hillslope response is associated with the process of subsurface storm flow and is mostly observed on convex hillslopes with deeply incised channels. The hillslope response is usually evaluated separately from the stream network response, which is the process of transport of all hillslope contributions toward the watershed outlet (Robinson and Sivapalan, 1996).

In Mediterranean and semi-arid watersheds, storm flow can follow a progression of dominance that begins with overland flow and ends with baseflow (Hallema et al., 2013), which is nearly the reverse of patterns observed under a temperate climate, where storm flow under saturated conditions is typically characterized by a progression of dominance by base flow, base flow diluted with channel precipitation and overland flow on zones that were already saturated at the beginning of the storm, overland flow, subsurface flow, or throughflow, and base flow mixed with seepage from saturated zones (Pionke and DeWalle 1994). This happens because nearzero infiltration conditions are common in Mediterranean and semi-arid hillslopes with soil surface sealing (structural crust), and last until the sealing layer is fully wetted. The time required for this wetting process can exceed the duration of a convective rainstorm, in which case, runoff is dominated by infiltration-excess runoff and may be extended further as a result of the rainsplash occurring during the storm itself. This phenomenon can boost overland flow contributions to peak flows of $80 \%$ in headwater catchments (Ribolzi et al., 2000). Many variations of flow progression exist, given that storm flow generation depends on climatic conditions, geology, soil, and topography; however, in most cases, the effect of evapotranspiration on the storm flow water balance is negligible for the duration of the storm due to cloud cover (Hallema et al., 2013). The hillslope response and 
stream network response combined give the watershed response, where their relative importance depends on the watershed shape and size. Hillslope response is more important relative to stream responses in smaller watersheds because the relative residence time of water on these hillslopes is relatively long (Robinson et al., 1995; Wooding, 1965), and therefore, understanding the hillslope response is essential for effective water management and flood forecasting.

\section{Modeling hillslope surface response}

The appropriate model complexity for a particular situation depends on the intended purpose of the model. Computational modeling involves parameterization, where the number of calibration parameters are reduced (Refsgaard, 1997). The principle of parsimony dictates that models should have the simplest possible parameterization that correctly represents the data according to a set of predefined criteria (Box and Jenkins, 1976).

\section{Evolution of hillslope response models}

A parsimonious model for storm flow response will account for the mere sum plus the interaction of runoff contributing processes, and the first to develop such a model was most likely Horton (1938). His model was a simplification of the Saint-Venant (shallow water) equations formulated for overland flow. Under the kinematic assumption that the friction slope equals the bed slope (Henderson and Wooding, 1964) and assuming transitional flow conditions, i.e., a water surface profile with a transitional flow regime between laminar and turbulent flow, Horton defined a one-dimensional, non-linear storage-based overland flow model. The non-linear relationship between rainfall intensity and hillslope response was found following an analytical solution of the differential equation governing flow on the hillslope. Horton's storage-based model does not account for spatial variability in rainfall, topography, and surface roughness; nevertheless, it is believed to be equivalent in accuracy to more complex models when applied to the watershed scale (Robinson et al., 1996).

Robinson et al. (1995) and Robinson and Sivapalan (1996) used the approximate quasi-steady-state formulation of Horton (1938) and Rose et al. (1983) to establish the analytical solutions of the mass balance equations and define separate lumped hillslope models for overland flow and subsurface storm flow. These were then used to derive the instantaneous response functions (IRF), which defines the rate of runoff generation at the base of a hillslope in terms of its length along the contributing surface, gradient, depth of flow, surface storage, and rainfall excess. Robinson and Sivapalan's approximate solution to the overland flow equation was further elaborated by
Agnese et al. (2001) to obtain a hillslope response model for overland flow, which expressed the time required to obtain a steady ratio of runoff to rainfall in a function that depends on the initial flow conditions, rainfall excess, a hillslope geometry parameter, and a parameter indicating the flow regime. This hillslope response model for overland flow has an important advantage over Horton's model (Horton, 1938), namely that it accounts for laminar, turbulent, and transitional flow regimes and not only for transitional flow.

More recent models such as the hillslope-storage Boussinesq (HSB; Troch et al., 2003) model explicitly account for subsurface storm flow in terms of profile curvature and plan shape. This model is based on Boussinesq's hydraulic groundwater theory formulated in terms of subsurface water storage, and results demonstrated that convergent hillslopes drain more slowly than divergent hillslope, yielding a bell-shaped hydrograph versus a highly peaked hydrograph due to a reduced flow domain near the outlet for convergent slopes (Troch et al., 2003). The HSB model compared well to more complex models of subsurface flow such as the three-dimension Richards equation (Paniconi et al., 2003); however, it has never been used for storm flow modeling at the watershed scale (Matonse and Kroll, 2009).

More process-based integrated distributed hydrological models such as Gestion Intégrée des Bassins versants à l'aide d'un Système Informatisé (GIBSI; Villeneuve et al., 1998; Rousseau et al., 2000) and Modélisation Hydrologique Distribuée des Agrosystèmes (MHYDAS; Moussa et al., 2002) rely on a defined spatial topology and account for a wide variety of hydrological processes at the watershed (MHYDAS) and basin (GIBSI) scales (infiltration, runoff, flow routing, nutrient cycling, erosion). These distributed models are very suitable for complex landscapes in agricultural and mixed land use watersheds, and have been used for storm flow modeling (Hallema et al., 2013), erosion control studies (Gumiere et al., 2013; Gosselin et al. 2016), and the assessment of agricultural best management practices (Rousseau et al., 2013). Runoff velocities and parameterization of physically based erosion models are often based on the topographic attributes calculated from digital elevation models, and vary spatially depending on the position along the hillslope (e.g., hillslope elements defined by Ruhe).

Notwithstanding, the versatility and usefulness of integrated distributed hydrological models, parameterization requires substantial amounts of spatial data (Hallema et al., 2013), which can be difficult to obtain for soil hydraulic models in particular (Gumiere et al., 2015; Hallema et al., 2015a, b). Other challenges include defining the initial state of the system (e.g., initial soil 
moisture content; Hallema et al., 2013; 2014), and in terms of model parsimony, the question is often what the physical meaning is when the results of process models formulated for a smaller scale (e.g., infiltration models) are upscaled to the hillslope and watershed scales.

\section{Modeling hydrologic connectivity with the geomorphologic instantaneous unit hydrograph (GIUH) approach}

Where hydrological data are sparse, scaling issues in surface runoff modeling can be dealt more effectively by integrating topographical indicators of structural hydrologic connectivity. Topographic attributes affect flow and travel time distributions along the hillslope in several ways: the gradient of the hillslope affects the amount of runoff generated and the gravitational acceleration of overland flow and channel flow. Slope curvature affects flow patterns by converging or diverging flow paths along the hillslope. Rodríguez-Iturbe and Valdés (1979) proposed a unifying theory that links the instantaneous unit hydrograph (IUH; which is the direct runoff hydrograph produced during a storm in response to a unit of rainfall) to the geomorphologic parameters of the watershed. This yielded the GIUH, a conceptual model of overland and stream flow routing at the watershed scale. The GIUH was later formalized by Rinaldo and Rodríguez-Iturbe (1996) and assumes that when rainfall is applied uniformly on the watershed, runoff is also generated uniformly. Thus, the theory provides a description of the structural connectivity between the hillslopes and channel network.

General equations were proposed that express the GIUH as a function of Horton's bifurcation ratio $R_{B}$, length ratio $R_{L}$, area ratio $R_{A}$, scale parameter $L_{\omega}$ and the mean stream flow velocity $v_{c}$. The GIUH based on Horton's ratios was subsequently used to simulate hydrologic response under various conditions (Gupta and Waymire, 1998; Saco and Kumar, 2002a, 2002b; Bhunya et al., 2003; Rodríguez et al., 2005; Kumar et al., 2007; Singh et al., 2007; Bhunya et al., 2008; Lee et al., 2008), and even to estimate peak flows (Sorman, 1995). The GIUH can be applied for a wide range of watersheds and storm characteristics because its variability is accounted for by flow velocity parameters, and this makes the GIUH a very parsimonious model. In addition, it avoids numerical instabilities for which the diffusion and kinematic wave approximations are known.

Other formulations of the GIUH are based on the geomorphologic width function $w_{j}(x)$ (WFIUH; Shreve, 1969; Kirkby, 1976), which defines the lines of equal flow distance from the watershed outlet and is considered more accurate than GIUHs based on Strahler's and Horton's order ratios (Snell and Sivapalan 1994). Assuming that the runoff wave is not attenuated as it travels along the hillslopes and channel network, the WFIUH is a function of flow velocity and distance. The geomorphologic width function uses the underlying assumption of the GIUH theory that takes the IUH equal to the probability density function of the travel times between any location within the watershed and the watershed outlet. It can therefore be used to express the hydrologic response of the stream network to an instantaneous rainfall (Mesa and Mifflin 1986). When this approach is applied to the entire hillslope or watershed, the width function defines the number of links at a given flow length from a given outlet, which is a function of the flow distances and flow velocity distribution on hillslopes and in the stream network.

\section{Illustration of storm flow modeling with the width function- based geomorphologic instantaneous unit hydrograph (WFIUH)}

Hydrograph prediction is a key element of flood forecasting in watersheds; however, the reality of hydrologic modeling is that we deal with a wide range of topographical complexity for any given hillslope. Cultivated hillslopes and urban environments no longer have natural gradients, and surface channel networks have a greater drainage density, resulting in connectivity patterns that are more complex relative to natural connectivity patterns on undisturbed hillslopes (Hallema and Moussa, 2014). Agricultural fields also have a generally lower canopy density than the natural vegetation (Fig. 1), which makes them more vulnerable to erosion and nutrient flushing. Ruhe's subdivision of the hillslope into hillslope elements based on profile curvature is not very suitable for these environments; therefore, Hallema and Moussa (2014) proposed to subdivide the hillslope into representative elementary hillslopes (REH) where flow is considered uniform and unidirectional. Assuming flow rate $v_{h}$ for surface runoff, $v_{c, t}$ for flow in transverse channels (perpendicular to the slope direction), and $v_{c, l}$ for flow in longitudinal channels (parallel to the hillslope), and assuming that the runoff wave is not dispersed as it propagates down the hillslopes and channels, the hydrograph can be found by solving the width function for the entire hillslope (Hallema and Moussa, 2014). The integral of all width functions $w_{j}(x)$ for an REH equals the REH drainage area $A_{j}$ :

$$
\int_{0}^{L \max } w_{j}(x) d x=A_{j}
$$

where $L_{\max }$ is the maximum flow distance (length of the longest flow path) and $\mathrm{dx}$ is the length unit or cell length if a square grid is used to solve the width function. The GIUH of the spatial domain (hillslope, 


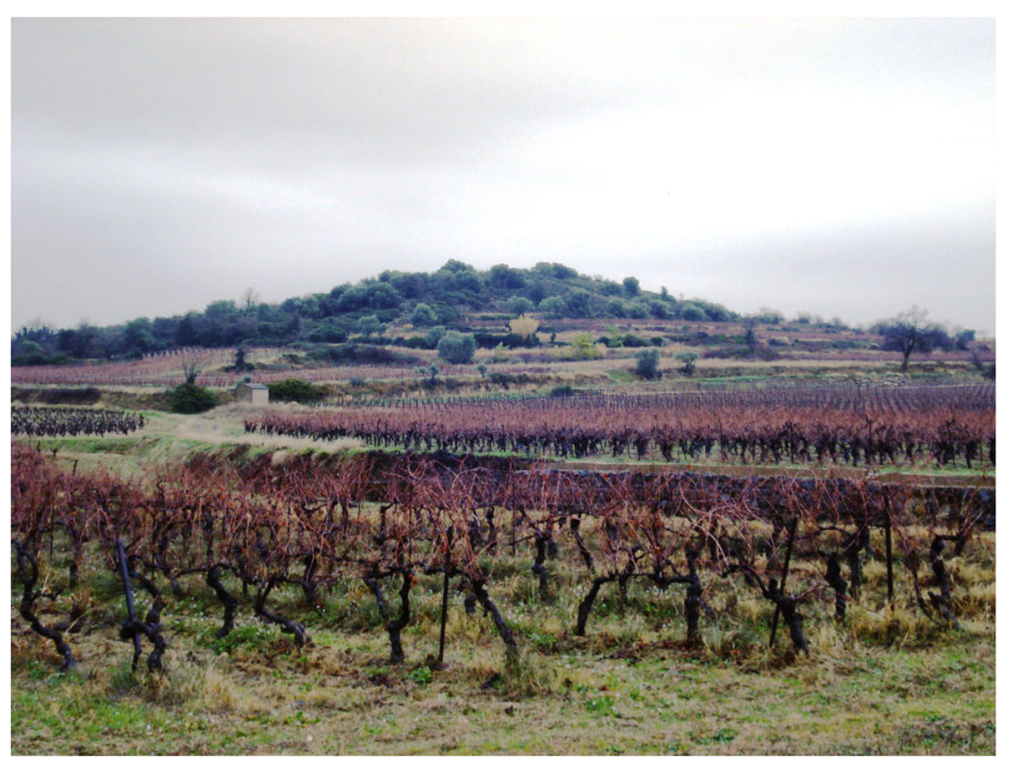

Fig. 1 Leaf cover on agricultural hillslopes is very sparse, which enhances rainfall impact at the soil surface and results in the formation of a sealing layer that impedes the infiltration process. High runoff rates are a common issue on these hillslopes

watershed, or basin) is the sum of all REH responses (Moussa, 1997; Moussa, 2008):

$$
W(x)=\sum_{J}^{J} w_{j}(x)
$$

where elementary width function $w_{j}(x)$ of the REH is characterized by (among others) peak flow $Q_{p}$, time of concentration $t_{c}$, and center of gravity of the hydrograph $t_{c g}$, in formula:

$$
w_{j}=f\left(Q_{p, j}, t_{c, j}, t_{c g, j}\right)
$$

Figure 2 shows the characteristic GIUH generated by an REH measuring $200 \times 50 \mathrm{~m}$ observed at the watershed outlet $O$ in response to a unit input and characteristic flow velocities in a Mediterranean cultivated watershed (Table 3; Hallema et al., 2013), compared to a scenario of increased drainage density (more channels). In this example, introducing an extra drainage channel on the hillslope results in accelerated runoff $\left(t_{c}\right.$ of 425 vs. $625 \mathrm{~s}$; Table 3$)$ and a $100 \%$ higher peak flow $\left(Q_{p}\right.$ of 0.02 vs. $0.01 \mathrm{~m}^{3} \mathrm{~s}^{-1}$ ).

The effect of topographic attributes on flow and travel time distributions is not limited to hillslopes but extends to zero and higher order catchments and to smaller scales such as the plot scale. A high level of connectivity between the hillslope and channel network increases the flashiness of the hydrologic regime, and this directly impacts the short-term variability in downstream outflow. On the other hand, there are cases where the connection between the hillslope and channel network is not well established, which can lead to inundations. Therefore, a proper characterization of flow paths, timing, and velocity distribution of runoff is essential in determining the flashiness of the hydrologic regime (Baker et al., 2004). The WFIUH has an important advantage over other models in this regard, because watershed-scale simulations can be performed by simply taking the sum of hillslope GIUHs and calculating a composite WFIUH that characterizes the hydrologic response of the watershed as a whole (Fig. 3).

\section{Discussion}

\section{WFIUH and the evaluation of ecosystem services}

The WFIUH model is a very useful tool for evaluating ecosystem services related flood risk assessment, runoff abatement, and erosion control, as illustrated in a previous study on the combined effects of drainage density and terrace cultivation in Southern France (Hallema and Moussa, 2014). Here, a greater drainage density resulted in accelerated runoff during storm rainfall, while an increased number of terrace levels along the hillslope diminished the surface gradient, thereby delaying response times and attenuating peak flows (Hallema and Moussa, 2014). These results are in line with observations in many other parts of the world (Di Lazzaro et al., 2015; Wei et al., 2016). For example, Kovár et al. (2016) found similar effects of agricultural terraces on storm runoff on a similar-sized hillslope in Bohemia (Czech Republic); however, they used the kinematic wave approximation to route storm flow because of lower rainfall intensities and a possibly greater relative contribution from subsurface flow compared to Mediterranean and semi-arid watersheds. 


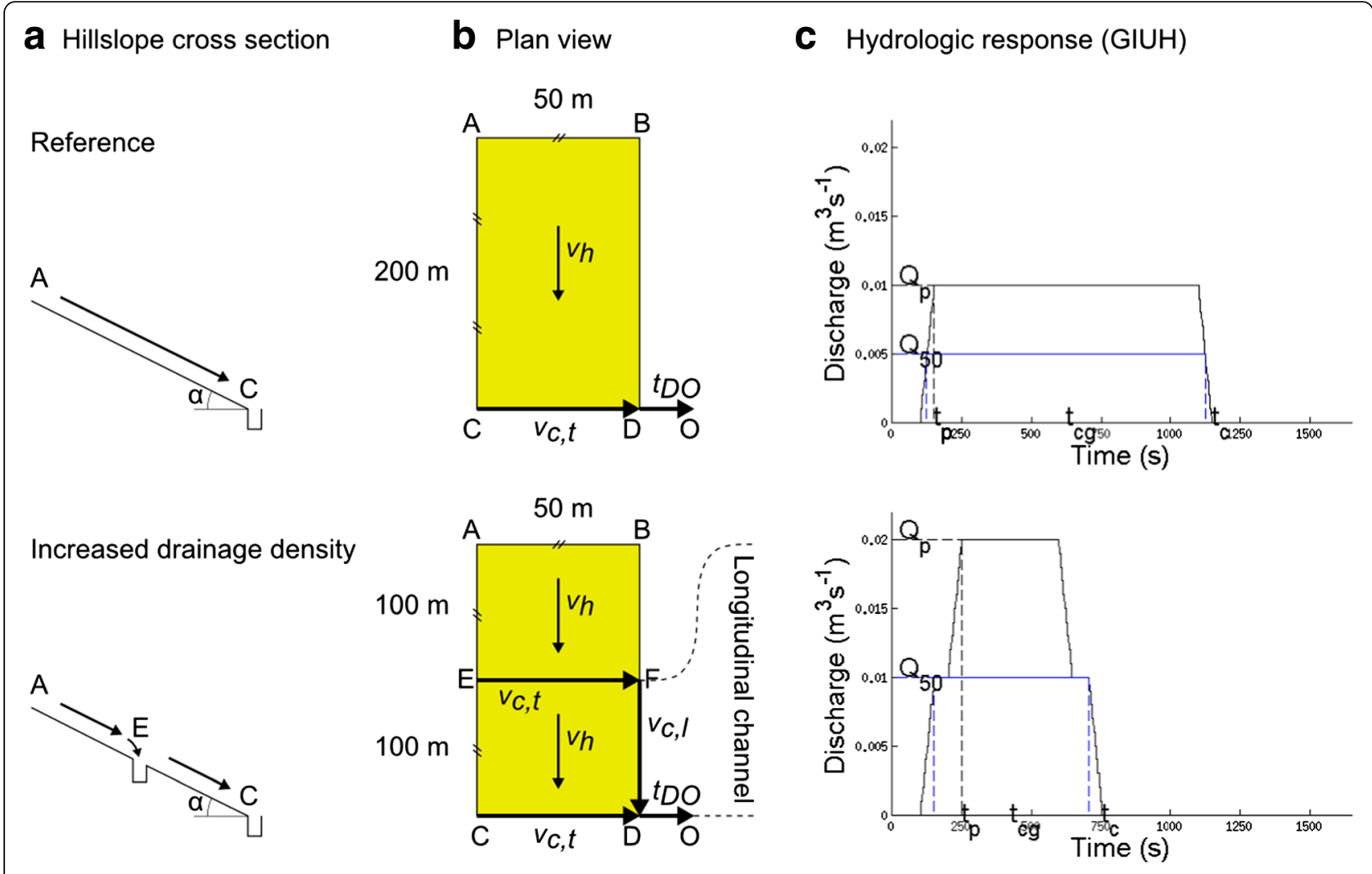

Fig. 2 Increased drainage density causes faster hillslope response and higher peak flows. a Hillslope cross section. b Plan view. c Hydrologic response $(\mathrm{GIUH})$

WFIUH-based runoff simulations are most accurate for systems dominated by surface processes, not because the underlying theory would not apply to subsurface flow but because flow paths of lateral subsurface drainage, groundwater, and preferential flow bypassing the soil matrix are extremely difficult to map or predict. The WFIUH can in fact be used to estimate the age of water, but this age often deviates from the age found in tracer studies (Rigon et al., 2016). Efforts were made to include estimates of evapotranspiration (ET) to improve estimates of travel time distributions (Botter et al., 2011), which has proven valuable for hydrochemical models in

Table 3 Characteristic hydrologic responses for the reference hillslope and hillslope with increased drainage density at watershed outlet $O$, for an input of $h=0.001 \mathrm{~m}$ and parameter values $A C=200 \mathrm{~m}, A B=50 \mathrm{~m}, v_{h}=0.2 \mathrm{~m} \mathrm{~s}^{-1}, v_{c, t}=1 \mathrm{~m} \mathrm{~s}^{-1}, v_{c, l}=$ $1 \mathrm{~m} \mathrm{~s}^{-1}$, travel time between the base of the hillslope and watershed outlet $t_{\mathrm{DO}}=100 \mathrm{~s}$, grid cell size $\mathrm{dx}=1 \mathrm{~m}$ and time interval $\mathrm{dt}=10 \mathrm{~s}$

\begin{tabular}{lclll}
\hline Hillslope scenario & $\mathrm{Q}_{p}\left(\mathrm{~m}^{3} \mathrm{~s}^{-1}\right)$ & $t_{p}(\mathrm{~s})$ & $t_{c}(\mathrm{~s})$ & $t_{c g}(\mathrm{~s})$ \\
\hline Reference & 0.01 & 148 & 1150 & 625 \\
Increased drainage density & 0.02 & 248 & 752 & 425 \\
\hline
\end{tabular}

$Q_{p}$ is simulated peak flow at the catchment outlet, $t_{p}$ is peak time, $t_{c}$ is time of concentration, and $t_{c g}$ is the center of gravity of the hydrograph temperate lowlands (Benettin et al., 2013). However, storm runoff predictions for environments dominated by Hortonian runoff such as those in the Mediterranean Region will not necessarily improve by accounting for ET because most water never infiltrates during the initial stage of a storm (Andrieux et al., 1996). Even at the surface where flow paths and local variations in topography can be mapped in great detail using LiDAR altimetry (Bailly et al., 2008; Cazorzi et al., 2013; Sofia et al., 2016) and validated with camera footage (Kean et al., 2013), the exact flow velocity distributions are often unknown and must be estimated based on slope and available data on surface roughness and vegetation.

Regardless, these limitations will likely disappear over time as sensor systems continue to evolve, and are outweighed by the benefits of using the WFIUH model of hydrologic connectivity for evaluating flood risk. Contrary to most distributed runoff models, the WFIUH describes the hydrologic response solely in terms of flow distance to a given outlet point meaning that all its parameters can be derived directly from a DEM or DTM. In the present era of LiDAR based DTMs, this also implies that we can better deal with the increasing complexity of runoff response to intense rainfall for a greater drainage area (Bel et al., 2016) by making optimal use of 


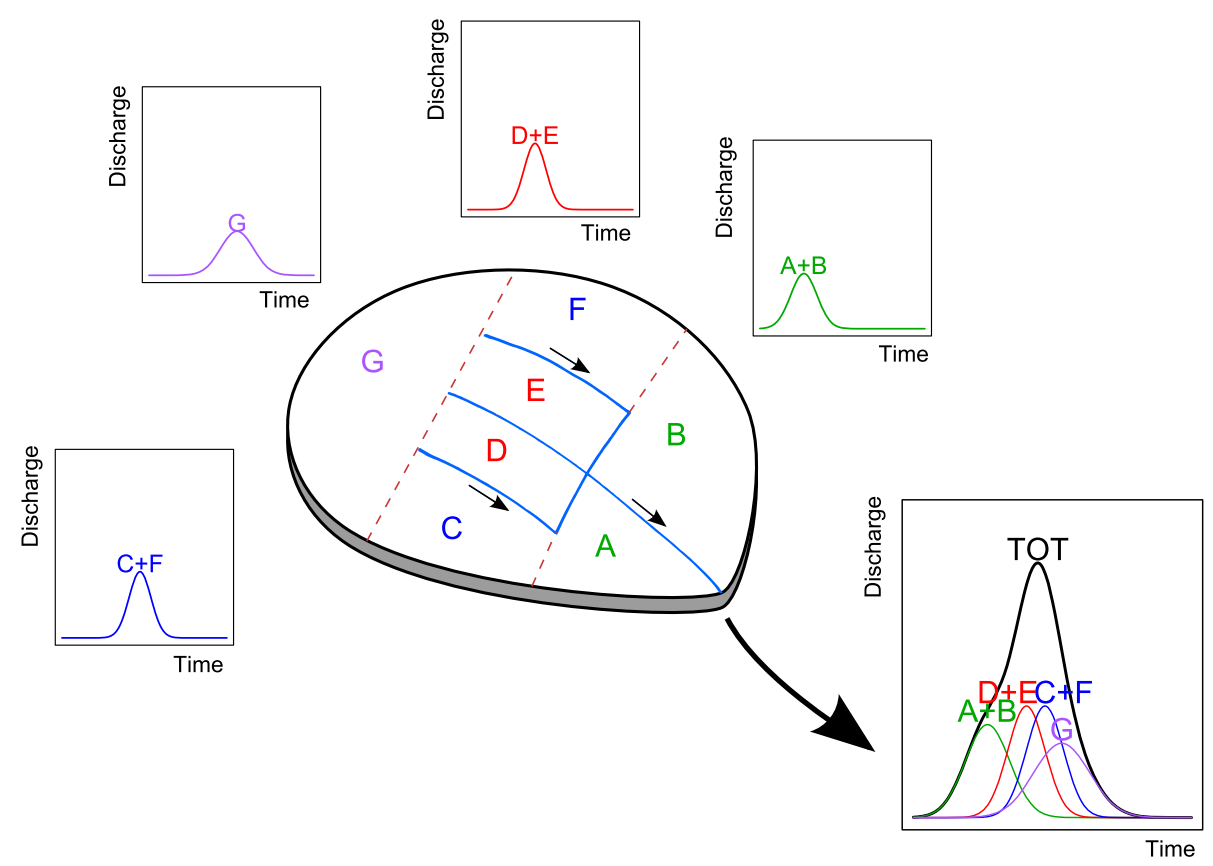

Fig. 3 The width function-based geomorphologic instantaneous unit hydrograph (WFIUH) of a watershed equals the sum of the WFIUHs of representative elementary hillslopes $A$ through $G$. The total runoff is a function of the travel time distribution within the watersheds, and varies depending on flow velocity and channel network configuration

the scalability of the GIUH. Applied to a variety of scales (hillslope to basin) and channel ramifications (dendritic or rectangular), the WFIUH contributes to the fundamental understanding of hydrologic connectivity across scales and the improvement of tools for modeling ecosystem services such as flood forecasting in response to land cover changes and climate variability.

\section{Future challenges}

Recent studies have explored the concept of functional hydraulic connectivity as a driver of Hortonian runoff and erosion (Reaney et al., 2014; Williams et al., 2016), which is different from structural connectivity in the sense that it accounts for the possibility that spatial patterns in the landscape (structural elements) can also change with time (Bracken et al., 2013). The functional connectivity is defined by dynamic processes such as the formation of preferential flow paths during storm rainfall, and oftentimes, the structural connectivity controls the functional connectivity and ecological processes, for example, when vegetation concentrates around existing runoff channels (Puigdefabrégas, 2005) and when wildfires create preferential surface flow paths (Moody et al., 2016). In the latter case, soil hydrophobicity resulting from heat effects creates patterns of variable wettability near the soil surface, where the burned areas can generate as much runoff as a paved surface, while the functional connectivity of unburned areas along the hillslope gradient has a large effect on runoff generation, reinfiltration, and propagation of concentrated flow (Moody et al., 2016). Once the two or three most significant processes affecting storm runoff have been identified (usually infiltration and open surface flow), spatial connectivity can be defined for each process separately and combined into one connectivity model. This approach can eventually lead to basin scale hydrologic models that preserve the parsimonious character of the width function, and will prove elementary in the understanding of hillslope response under a variety of conditions, including the effects of agriculture and wildland fire disturbance on runoff (Hallema and Moussa, 2014; Hallema et al. in review).

\section{Conclusions}

In this paper, we discussed the relation between hillslope topography and hillslope surface response and their impact on hydrologic connectivity along the hillslope and between the hillslope and the watershed during high intensity rainfall. The impact of these topographic attributes on flow and travel time distributions plays out along the entire hillslope and affects the amount of runoff delivered at the base of the hillslope and the stream network. We developed a runoff response model by simply determining the hydrologic connectivity from a DEM or DTM and adding the elementary responses of contributing flow paths at any point along a stream or drainage channel. The WFIUH thus provides a simple yet effective representation of runoff generation and flow 
propagation, thereby contributing to the improvement of tools for modeling ecosystem services such as flood forecasting in response to land cover changes and climate variability. Our work addresses the need for a watershed scale adaptation of the parsimonious GIUH-based model supported by the scaling issues encountered in the parameterization of process-based hydrological models, notably of soil hydraulic properties.

\section{Acknowledgements}

Financial support was provided by the Ministère de l'Enseignement supérieur et de la Recherche (MESR), Institut national de la recherche agronomique (INRA), SIBAGHE (Systèmes Intégrés en Biologie, Agronomie, Géosciences, Hydrosciences et Environnement), USDA Forest Service Eastern Forest Environmental Threat Assessment Center, Joint Fire Science Program \#14-1-0618, and the U.S. Forest Service Research Participation Program administered by the Oak Ridge Institute for Science and Education through an interagency agreement between the U.S. Department of Energy and the U.S. Department of Agriculture Forest Service. ORISE is managed by Oak Ridge Associated Universities (ORAU) under DOE contract number DE-AC05-06OR23100. All opinions expressed in this paper are the authors' and do not necessarily reflect the policies and views of MESR, INRA, SIBAGHE, USDA, DOE, or ORAU/ORISE.

\section{Authors' contributions}

DWH designed the study, managed and analyzed the data, created the model, and drafted the manuscript. RM designed the study, created the model, provided resources for the literature review, and reviewed the manuscript drafts. GS provided conceptual contributions and reviewed the manuscript drafts. SGM provided conceptual contributions and reviewed the manuscript drafts. All authors read and approved the final manuscript.

\section{Competing interests}

The authors declare that they have no competing interests.

\section{Author details}

'INRA, UMR LISAH Laboratoire d'étude des Interactions Sol-AgrosystèmeHydrosystème (INRA, IRD, Montpellier SupAgro), 2 place Pierre Viala, 34060 Montpellier CEDEX 2, France. ${ }^{2}$ U.S. Department of Agriculture Forest Service, Eastern Forest Environmental Threat Assessment Center, Southern Research Station, Raleigh, NC 27606, USA. ${ }^{3}$ U.S. Department of Energy, Oak Ridge Institute for Science and Education, Oak Ridge, TN 37830, USA.

Received: 24 May 2016 Accepted: 31 August 2016

Published online: 08 September 2016

\section{References}

Agnese C, Baiamonte G, Corrao C (2001) A simple model of hillslope response for overland flow generation. Hydrol Process 15(17):3225-3238. doi:10.1002/hyp.182

Andrieux P, Louchart X, Voltz M, Bourgeois T (1996) Déterminisme du partage infiltration-ruissellement sur parcelles de vigne en climat méditerranéen. In: Contribution des eaux souterraines au fonctionnement des hydrosystèmes, conséquences pour la gestion, vol 256, Editions du BRGM. Orléans, pp 7-1

Arnell NW, Gosling SN (2016) The impacts of climate change on river flood risk at the global scale. Clim Change 134(3):387. doi:10.1007/s10584-014-1084-5

Bailly JS, Lagacherie P, Millier C, Puech C, Kosuth P (2008) Agrarian landscapes linear features detection from LiDAR: application to artificial drainage networks. Int J Remote Sens 29(12):3489. doi:10.1080/01431160701469057

Baker DB, Richards RP, Loftus TT, Kramer J (2004) A new flashiness index: characteristics and applications to Midwestern rivers and streams. JAWRA 40(2):503-522

Bel C, Liébault F, Navratil O, Eckert N, Bellot H, Fontaine F, Laigle D (2016) Rainfall control of debris-flow triggering in the Réal Torrent, Southern French Prealps. Geomorphology. doi:10.1016/j.geomorph.2016.04.004, in press

Beven KJ, Kirkby MJ (1979) A physically based variable contributing area model of catchment hydrology. Hydrol Sci Bull 24(1):43-69

Beven K, Freer J, Hankin B, Schulz K (2000) Nonlinear and nonstationary signal processing, The use of generalised likelihood measures for uncertainty estimation in high-order models of environmental systems. Cambridge University Press, UK, pp 115-151

Bhunya PK, Mishra SK, Berndtsson R (2003) Simplified two-parameter gamma distribution for derivation of synthetic unit hydrograph. J Hydrol Eng 8:226-230

Bhunya PK, Berndtsson R, Singh PK, Hubert P (2008) Comparison between Weibull and gamma distributions to derive synthetic unit hydrograph using Horton ratios. Water Resour Res 44, W04421

Bogaart PW, Troch PA (2006) Curvature distribution within hillslopes and catchments and its effect on the hydrological response. Hydrol Earth Syst Sc 10:925-936

Botter G, Bertuzzo E, Rinaldo A (2011) Catchment residence and travel time distributions: the master equation. Geophys Res Lett 38(11):L11403. doi:10. 1029/2011GL047666, 1-6

Box G, Jenkins G (1976) Time series analysis: forecasting and control. Holden-Day, San Francisco

Bracken LJ, Croke J (2007) The concept of hydrological connectivity and its contribution to understanding runoff-dominated geomorphic systems. Hydrol Process 21:1749-1763. doi:10.1002/hyp.6313

Bracken L, Wainwright J, Ali GA, Tetzlaff D, Smith MW, Reaney SM, Roy AG (2013) Concepts of hydrological connectivity: research approaches, pathways and future agendas. Earth-Sci Rev 119:17-34. doi:10.1016/j.earscirev.2013.02.001

Burt T, Butcher D (1986) Stimulation from simulation-a teaching model of hillslope hydrology for use on microcomputers. J Geogr Higher Educ 10:23-39

Cammeraat LH (2002) A review of two strongly contrasting geomorphological systems within the context of scale. Earth Surf Process Landforms 27:1201-1222. doi:10.1002/esp.421

Cazorzi F, Dalla Fontana GD, De Luca A, Sofia G, Tarolli P (2013) Drainage network detection and assessment of network storage capacity in agrarian landscape. Hydrol Process 27:541-553. doi:10.1002/hyp.9224

Chahinian N, Moussa R, Andrieux P, Voltz M (2005) Comparison of infiltration models to simulate flood events at the field scale. J Hydrol 306(1-4):191-214

Chahinian N, Moussa R, Andrieux P, Voltz M (2006) Accounting for temporal variation in soil hydrological properties when simulating surface runoff on tilled plots. J Hydrol 326(1-4):135-152

Chow V, Maidment D, Mays L (1988) Applied hydrology. McGraw-Hill, New York

Dalrymple J, Blong R, Conacher A (1968) A hypothetical nine-unit landsurface model. Z Geomorphol NF 12:60-75

Di Lazzaro M, Zarlenga A, Volpi E (2015) Hydrological effects of within-catchment heterogeneity of drainage density. Adv Water Resour 76:157-167. doi:10.1016/j.advwatres.2014.12.011

Dunjó G, Pardini G, Gispert M (2004) The role of land use-land cover on runoff generation and sediment yield at a microplot scale, in a small Mediterranean catchment. J Arid Environ 57:99-116. doi:10.1016/S0140-1963(03)00097-1

Dunne T (1978) Field studies of hillslope flow processes. In: Kirkby MJ (ed) Hillslope Hydrology. Wiley, New York, pp 227-293

Dunne T, Black RD (1970) An experimental investigation of runoff production in permeable soils. Water Resour Res 6(2):478-490

Emmett W (1978) Overland flow. In: Kirkby MJ (ed) Hillslope Hydrology. Wiley, New York, pp 145-176

Fan Y, Bras R (1998) Analytical solutions to hillslope subsurface storm flow and saturation overland flow. Water Resour Res 34:921-927

Gosselin GH, Rousseau AN, Gumiere SJ, Hallema DW, Fortin CR, Thériault G, Van Bochove $E$ (2016) Modeling the sediment yield and the impact of vegetated filters using an event-based soil erosion model: a case study of a small Canadian watershed. Hydrol Process 30(16):2835-2850. doi:10.1002/hyp.10817

Green TR, Salas JD, Martinez A, Erskine RH (2007) Relating crop yield to topographic attributes using Spatial Analysis Neural Networks and regression. Geoderma 139:23-37. doi:10.1016/j.geoderma.2006.12.004

Gumiere SJ, Rousseau AN, Hallema DW, Isabelle PE (2013) Development of VFDM: a riparian vegetated filter dimensioning model for agricultural watersheds. Can Water Resour J 38(3):169-184. doi:10.1080/07011784.2013.830372

Gumiere SJ, Lafond JA, Hallema DW, Périard Y, Caron J, Gallichand J (2015) Mapping soil hydraulic conductivity and matric potential for water management of cranberry: characterisation and spatial interpolation methods. Biosyst Eng 128:29-40. doi:10.1016/j.biosystemseng.2014.09.002

Gupta V. K.,Waymire, E. C. (1998) Ch. 4. Spatial Variability and scale invariance in hydrologic regionalization. Scale dependence and scale invariance in hydrology. Cambridge University Press: Cambridge, UK; 88-135

Guswa AJ, Brauman KA, Brown C, Hamel P, Keeler BL, Sayre SS (2014) Ecosystem services: challenges and opportunities for hydrologic modeling to support decision making. Water Resour Res 50. doi:10.1002/2014WR015497 
Hack JT, Goodlett J (1960) Geomorphology and forest ecology of a mountain region in the Central Appalachians. United States Geological Survey, Professional Papers, Washington, D.C, p 347

Hallema, D. W., Sun, G., Caldwell, P. V., Norman, S. P., Cohen, E. C., Liu, Y., Ward, E. J., McNulty, S. G. Assessment of wildland fire impacts on watershed annual water yield: analytical framework and case studies in the United States. Ecohydrology. (in review).

Hallema DW, Moussa R (2014) A model for distributed GIUH-based flow routing on natural and anthropogenic hillslopes. Hydrol Process 28:4877-4895. doi: 10.1002/hyp.9984

Hallema DW, Moussa R, Andrieux P, Voltz M (2013) Parameterization and multicriteria calibration of a distributed storm flow model applied to a Mediterranean agricultural catchment. Hydrol Process 27:1379-1398. doi:10.1002/hyp.9268

Hallema DW, Rousseau AN, Gumiere SJ, Périard Y, Hiemstra PH, Bouttier L, Fossey M, Paquette A, Cogliastro A, Olivier A (2014) Framework for studying the hydrological impact of climate change in an alley cropping system. J Hydrol 517:547-556. doi:10.1016/j.jhydrol.2014.05.065

Hallema DW, Lafond JA, Périard Y, Gumiere SJ, Sun G, Caron J (2015a) Long-term effects of peatland cultivation on soil physical and hydraulic properties: case study in Canada. Vadose Zone J 14(6). doi:10.2136/vzj2014.10.0147

Hallema DW, Périard Y, Lafond JA, Gumiere SJ, Caron J (2015b) Characterization of water retention curves for cultivated Histosols. Vadose Zone J 14(6). doi:10.2136/vzj2014.10.0148

Henderson FM, Wooding RA (1964) Overland flow and groundwater flow from a steady rainfall of finite duration. J Geophys Res 69:1531-1540. doi:10.1029/ JZO69i008p01531

Hewlett JD, Hibbert AR (1967) Factors affecting the response of small watersheds in precipitation in humid areas. In: Sopper WE, Lull HW (eds) Proceedings of International Symposium on Hydrology. Pergamon Press, New York, pp 275-290

Horton RE (1933) The role of infiltration in the hydrologic cycle. Am Geophys Union 14:446-460

Horton RE (1938) The interpretation and application of runoff experiments with reference to soil erosion. Soil Scie Soc Am Proc 3:340-349

Huggett RJ (2007) Fundamentals of geomorphology, 2nd edn. Routledge, New York

Jencso KG, McGlynn BL, Gooseff MN, Wondzell SM, Bencala KE, Marshall LA (2009) Hydrologic connectivity between landscapes and streams: transferring reach- and plot-scale understanding to the catchment scale. Water Resour Res 45, W04428. doi:10.1029/2008WR007225

Kean JW, McCoy SW, Tucker GE, Staley DM, Coe JA (2013) Runoff-generated debris flow: observations and modeling of surge initiation, magnitude, and frequency

King L (1953) Canons of landscape evolution. Geol Soc Am Bull 64:721-752

Kirkby MJ (1976) Tests of the random model and its application to basin hydrology. Earth Surf Proc Land 1:197-212

Kovář P, Bačinová H, Loula J, Fedorova D (2016) Use of terraces to mitigate the impacts of overland flow and erosion on a catchment. Plant Soil Environ 62(4):171-177. doi:10.17221/786/2015-PSE

Kumar R, Chatterjee C, Singh RD, Lohani AK, Kumar S (2007) Runoff estimation for an ungauged catchment using geomorphological instantaneous unit hydrograph GIUH models. Hydrol Process 21:1829-1840

Lee KT, Chen N-C, Chung Y-R (2008) Derivation of variable IUH corresponding to time-varying rainfall intensity during storms. Hydrolog Sci J 53(2):323-337

Mandelbrot BB (1982) The fractal geometry of nature. W. H. Freeman and Co. New York

Martínez-Casanovas JA, Ramos MC, Ribes-Dasi M (2002) Soil erosion caused by extreme rainfall events: mapping and quantification in agricultural plots from very detailed digital elevation models. Geoderma 105:125-140

Matonse AH, Kroll C (2009) Simulating low streamflows with hillslope storage models. Water Resour Res 45, W01407. doi:10.1029/2007WR006529

McGlynn BL, McDonnell JJ (2003) Quantifying the relative contributions of riparian and hillslope zones to catchment runoff. Water Resour Res 39(11):1310. doi:10.1029/2003WR002091

McGuire KJ, McDonnell JJ (2010) Hydrological connectivity of hillslopes and streams: characteristic time scales and nonlinearities. Water Resour Res 46, W10543. doi:10.1029/2010WR009341

Mesa OJ, Mifflin ER (1986) On the relative role of hillslope and network geometry in the hydraulic response. In: Gupta VK, Rodriguez-Iturbe I, Wood EF (eds) Scale problems in hydrology. D. Reidel Publishing Company, Norwell, pp 1-17

Moody JA, Ebel BA, Nyman P, Martin DA, Stoof CR, McKinley R (2016) Relations between soil hydraulic properties and burn severity. Int J Wildland Fire 25: 279-293. doi:10.1071/WF14062
Morgan RPC (1980) Field studies of sediment transport by overland flow. Earth Surf Proc 5(4):307-316. doi:10.1002/esp.3760050403

Moussa R (1997) Geomorphological transfer function calculated from digital elevation models for distributed hydrological modelling. Hydrol Process 11(5):429-449

Moussa R (2008) What controls the width function shape, and can it be used for channel network comparison and regionalization? Water Resour Res 44, W08456

Moussa R, Voltz M, Andrieux P (2002) Effects of the spatial organization of agricultural management on the hydrological behaviour of a farmed catchment during flood events. Hydrol Process 16(2):393-412. doi:10.1002/hyp.333

Nelson E, Mendoza G, Regetz J, Polasky S, Tallis H, Cameron DR, Chain KMA, Daily GC, Goldstein J, Kareiva PM, Lonsdorf E, Naidoo R, Ricketts TH, Shaw MR (2009) Modeling multiple ecosystem services, biodiversity conservation, commodity production, and tradeoffs at landscape scales. Front Ecol Environ 7(1):4-11. doi:10.1890/080023

Nirupama N, Simonovic SP (2007) Increase of flood risk due to urbanization: a Canadian example. Nat Hazards 40:25-41. doi:10.1007/s11069-006-0003-0

Paniconi C, Troch PA, Van Loon EE, Hilberts AGJ (2003) Hillslope-storage Boussinesq model for subsurface flow and variable source areas along complex hillslopes: 2. Intercomparison with a three-dimensional Richards equation model. Water Resour Res 39(11):1317-1334. doi:10.1029/ 2002WR001730

Pionke H, DeWalle D (1994) Streamflow generation on a small agricultural catchment during autumn recharge: I. Nonstormflow periods. J Hydrol 163(1-2):1-22. doi:10.1016/0022-1694(94)90019-1

Puigdefabrégas J (2005) The role of vegetation patterns in structuring runoff and sediment fluxes in drylands. Earth Surf Process Landforms 30:133-147. doi:10.1002/esp.1181

Reaney SM, Bracken LJ, Kirkby MJ (2014) The importance of surface controls on overland flow connectivity in semi-arid environments: results from a numerical experimental approach. Hydrol Process 28:2116-2128. doi:10.1002/HYP.9769

Refsgaard JC (1997) Parameterisation, calibration and validation of distributed hydrological models. J Hydrol 198:69-97

Ribolzi O, Andrieux P, Valles V, Bouzigues R, Bariac T, Voltz M (2000) Contribution of groundwater and overland flows to storm flow generation in a cultivated Mediterranean catchment. Quantification by natural chemical tracing. J Hydrol 233(1-4):241-257. doi:10.1016/S0022-1694(00)00238-9

Rigon R, Bancheri M, Giuseppe F, De Lavenne A (2016) The geomorphological unit hydrograph from a historical-critical perspective. Earth Surf Process Landforms 41:27-37. doi:10.1002/esp.3855

Rinaldo A, Rodríguez-lturbe I (1996) Geomorphological theory of the hydrological response. Hydrol Process 10(6):803-829. doi:10.1002/(SICI)10991085(199606)10:6<803::AID-HYP373>3.0.CO;2-N

Rinaldo A, Rodríguez-Iturbe I, Rigon R, Bras R, ljjász-Vásquez E, Marani A (1992) Minimum energy and fractal structure of drainage networks. Water Resour Res 28:2183-2195

Rinaldo A, Rodríguez-Iturbe I, Rigon R (1998) Channel networks. Annu Rev Earth PI Sc 26:289-327

Robinson JS, Sivapalan M (1996) Instantaneous response functions of overland flow and subsurface stormflow for catchment models. Hydrol Process 10(6): 845-862. doi:10.1002/(SICI) 1099-1085(199606)10:6<845::AID-HYP375>3.0.CO;2-7

Robinson JS, Sivapalan M, Snell JD (1995) On the relative roles of hillslope processes, channel routing, and network geomorphology in the hydrologic response of natural catchments. Water Resour Res 31(12):3089-3101

Rodhe A, Seibert J (1999) Wetland occurrence in relation to topography: a test of topographic indices as moisture indicators. Agr Forest Meteorol 98-99:325-340

Rodríguez F, Cudennec C, Andrieu H (2005) Application of morphological approaches to determine unit hydrographs of urban catchments. Hydrol Process 19:1021-1035

Rodríguez-Iturbe I, Rinaldo A (1997) Fractal river basins, chance and self-organization. Cambridge University Press, Cambridge

Rodríguez-lturbe I, Valdés JB (1979) The geomorphologic structure of hydrologic response. Water Resour Res 15(6):1409-1420

Rose CW, Parlange JY, Sander GC, Campbell SY, Barry DA (1983) Kinematic flow approximation to runoff on a plane: an approximate analytic solution. J Hydrol 62(1-4):363-369. doi:10.1016/0022-1694(83)90113-0

Rousseau AN, Mailhot A, Turcotte R, Duchemin M, Blanchette C, Roux M, Dupont J, Villeneuve JP (2000) GIBSI: an integrated modelling system prototype for river basin management. Hydrobiologia 422-423:465-475 
Rousseau AN, Savary S, Hallema DW, Gumiere SJ, Foulon E (2013) Modeling the effects of agricultural BMPs on sediments, nutrients, and water quality of the Beaurivage River watershed (Quebec, Canada). Can Water Resour J 38(2):99-120. doi:10.1080/07011784.2013.780792

Rubin J (1966) Theory of rainfall uptake by soils initially drier than their field capacity and its applications. Water Resour Res 2:739-749

Ruhe R (1960) Elements of the soil landscape. Trans Int Congr Soil Sci 4: 165-170, 7th

Saco PM, Kumar P (2002a) Kinematic dispersion in stream networks 1. Coupling hydraulic and network geometry. Water Resour Res 38:1244

Saco PM, Kumar P (2002b) Kinematic dispersion in stream networks 2. Scale issues and self-similar network organization. Water Resour Res 38:1245

Schaefer M, Elifrits D, Barr DJ (1979) Sculpturing reclaimed land to decrease erosion, Paper presented at the Symposium on Surface Mining Hydrology, Sedimentology and Reclamation. University of Lexington, Kentucky

Seibert J, Bishop KH, Nyberg L (1997) A test of TOPMODEL's ability to predict spatially distributed groundwater levels. Hydrol Process 11:1131-1144

Shafroth PB, Wilcox AC, Lytle DA, Hickey JT, Andersen DC, Beauchamp VB, Hautzinger A, McMullen LE, Warner A (2010) Ecosystem effects of environmental flows: modelling and experimental floods in a dryland river. Freshwater Biol 55:68-85. doi:10.1111/j.1365-2427.2009.02271.x

Shreve R (1969) Stream lengths and basin areas in topologically random channel networks. J Geol 77:397-414

Singh PK, Bhunya PK, Mishra SK, Chaube UC (2007) An extended hybrid model for synthetic unit hydrograph derivation. J Hydrol 336(3-4):347-360

Snell J, Sivapalan M (1994) On geomorphological dispersion in natural catchments and the geomorphological unit hydrograph. Water Resour Res 4: $2311-2323$

Sorman AU (1995) Estimation of peak discharge using GIUH model in Saudi Arabia. J Water Resour Plan Manag 121:287

Climate Analysis Service (2004) Oregon State Univ., http://www.prism. oregonstate.edu/

Thommeret N, Bailly JS, Puech C (2010) Extraction of thalweg networks from DTM's: application to badlands. Hydrol Earth Syst Sc 14:1527-1536

Thorp JH, Flotemersch JE, Delong MD, Casper AF, Thoms MC, Ballantyne F, Williams BS, O'Neill BJ, Haase CS (2010) Linking ecosystem services, rehabilitation, and river hydrogeomorphology. Bioscience 60(1):67-74. doi:10.1525/bio.2010.60.1.11

Troch PA, Paniconi C, Van Loon E (2003) Hillslope-storage Boussinesq model for subsurface flow and variable source areas along complex hillslopes: 1. Formulation and characteristic reponse. Water Resour Res 39(11):WR001728. doi:10.1029/2002WR001728

Tucker GE, Bras RL (1998) Hillslope processes, drainage density, and landscape morphology. Water Resour Res 34(10):2751-2764

Turnbull L, Wainwright J, Brazier RE (2008) A conceptual framework for understanding semi-arid land degradation: ecohydrological interactions across multiple-space and time scales. Ecohydrology 1:23-34

Uchida T, Asano Y, Onda Y, Miyata S (2005) Are headwaters just the sum of hillslopes? Hydrol Process 19(16):3251-3261. doi:10.1002/hyp.6004

Villeneuve JP, Blanchette C, Duchemin M, Gagnon JF, Mailhot A, Rousseau AN, Roux M, Tremblay S, Turcotte R (1998) Rapport Final du Projet GIBSI: Gestion de l'Eau des Bassins Versants à l'Aide d'un Système Informatisé. Report R-462. Tome 1. Sainte-Foy: INRS -Eau

Wagener T, Wheater HS, Gupta HV (2004) Rainfall-runoff modelling in gauged and ungauged catchments. Imperial College Press, London

Wainwright J, Turnbull L, Ibrahim TG, Lexartza-Artza I, Thornton SF, Brazier RE (2011) Linking environment régime, space and time: interpretations of structural and functional connectivity. Geomorphology 126:387-404. doi:10.1016/j.geomorph.2010.07.027

Wei W, Chen D, Wang L, Daryanto S, Chen L, Yu Y, Lu Y, Sun G, Feng T (2016) Global synthesis of the classifications, distributions, benefits and issues of terracing. Earth Sci Rev 159:388-403. doi:10.1016/j.earscirev.2016.06.010

Williams CJ, Pierson FB, Robichaud PR, Al-Hamdan OZ, Boll J, Strand EK (2016) Structural and functional connectivity as a driver of hillslope erosion following disturbance. Int J Wildland Fire 25:306-321. doi:10.1071/WF14114

Wood A (1942) The development of hillside slopes. Geol Assoc Proc 53:128-138

Wooding R (1965) A hydraulic model for the catchment-stream problem: II. Numerical solutions. J Hydrol 3(3-4):268-282. doi:10.1016/0022-1694(65)90085-5
Young, A. (1971) Slope profile analysis: the systems of best units. In: Brunsden, D. (Ed.), Slopes form and process. Institute of British Geographers Special Publication No. 3. Institute of British Geographers, Kensington Gore, London, pp. 1-13

Zhang Y-K, Schilling KE (2006) Increasing streamflow and baseflow in the Mississippi River since the 1940s: effect of land use change. J Hydrol 324(1-4):412-422. doi:10.1016/j.jhydrol.2005.09.033

\section{Submit your manuscript to a SpringerOpen ${ }^{\circ}$ journal and benefit from:}

- Convenient online submission

- Rigorous peer review

- Immediate publication on acceptance

- Open access: articles freely available online

- High visibility within the field

- Retaining the copyright to your article

Submit your next manuscript at $>$ springeropen.com 